\title{
6
}

\section{Bigger and Bigger: Shipping During the Golden Age, 1950-73}

Hvor seiler vi? [Where are we sailing?] was a series of four programmes aired in late 1969 by Norsk Rikskringkasting. The TV series was not what we would consider classic Friday night entertainment, but rather the kind of programme that could only be broadcast in a country with a single state-owned television channel. In a curious mix of entertainment and public education, the programme presented some of the main European ports frequented by Norwegian sailors. The programmemakers-including Gunnar Bull-Gundersen, who had a background as welfare officer in the merchant marine-visited the main European port cities, Antwerp, Amsterdam, Rotterdam and London, sending home very vivid portrayals of the sailors' lives there.

Norwegian sailors, and employees in the local "entertainment industry" that had been set up to serve them, were interviewed in bars that could at best be considered dives. Both the interview subjects and the interviewer were frequently filmed with a beer and a cigarette in hand. Among the highlights of the programmes was a five-minute story, in broken Norwegian, where a Dutch bar hostess in Antwerp explained that she 
knew what to do with drunken sailors_-she would beat them up whenever they were slow to pay their debts. ${ }^{1}$

In the ports were parallel Norwegian societies, made up of uteseilere [sailors based abroad] - seafarers that for various reasons seldom or never visited their home country. ${ }^{2}$ Rather than going back to Norway, they frequented bars_-often offering accommodation as well-with local names such as Bergen Bar, Tønsberg Bar, Telemarken, Café Måneskinn [Moonshine], Café Solskinn [Sunshine] and Café Håpløs [Hopeless].

Uteseilere were sometimes portrayed as a romantic group, with "saltwater in their veins" and a carefree life from port to port, with a drink in one hand and a local girlfriend in the other. However, the sailors interviewed in the TV series-both those based abroad and those still living in Norway-lamented the manner in which the shipping sector had developed. Specifically, the effects of the technological development on seafaring life were presented as problematic. Due to the improved efficiency of shipping, in particular with regard to loading and unloading, long stays in exciting port cities had been replaced by very brief stopovers at isolated and uninteresting terminals: "Those who dreamt of experiences in foreign ports, did not meet anything but the dreary reality of the eternally long oil pipes." 3

Rather than a lively port city, the sailors frequently found themselves in places such as Europoort, "30 kilometres from Rotterdam and seven kilometres from the closest neighbour." 4 The Norwegian seamen's church even constructed a chapel there, functioning as an annex to the main church in Rotterdam, because the mobility of the seamen was

\footnotetext{
${ }^{1}$ The Dutch bar hostess, married to a Norwegian and working in a seamen's bar in a Belgian port city, is an illustration of the truly international environment that seafarers were exposed to, in a period where travels abroad, whether for business or pleasure, were far less common than today.

${ }^{2}$ A somewhat caricatured presentation of an uteseiler was someone who signed off in foreign ports, and stayed there-drinking heavily — until money issues or other problems forced them to sign on a new vessel. The TV series aimed at nuancing this picture, but was criticized for the decision to interview and portray sailors in typical red light district bars, rather than in the local seamen's church. One critic suggested that every one of the 32 Norwegian seamen's churches abroad should have been visited, in order to give the programme the right balance; Gundersen $(1970,10)$.

${ }^{3}$ Gundersen $(1970,77)$.

${ }^{4}$ NRK, "Hvor seiler vi," 271169.
} 
increasingly limited. Rationalization and new technologies also implied that life on-board had become more isolated, with fewer colleagues and more solitary work. For the modern seafarer, the physical hardship in the masts or the engine room had been replaced by the mental strain of a lonely life.

In the first post-war decades, two technological trends worked together, and both had a numbing effect on seafaring life. First, vessels became larger and larger, which explains why they had to anchor up in more remote areas. Second, the ships became more specialized, purpose-built to transport a relatively small variety of goods. By designing vessels that were specialized for specific cargoes, the loading and unloading became much more efficient. The time spent in port declined from weeks to days, and as port time was reduced, the monotonous days at sea became more plentiful.

Both of these technological trends were possible as a result of the growing volumes of seaborne transport. The first post-war decades saw a strong increase in world trade. The world economy had clearly rediscovered the growth momentum that had been lost in Sarajevo more than three decades earlier.

\section{The Golden Age}

With two devastating wars and The Great Depression, Europe had squandered much of the potential for income growth in the first half of the 20 th century. Figure 6.1 provides a visual representation of economic growth in the 20th century, which reveals the manner in which decades of potential growth were lost to fighting and crisis. ${ }^{5}$ The dotted line represents the average long-term growth rate of Gross Domestic Product (GDP) per capita in Western Europe. This growth-1.87 per cent annu-

\footnotetext{
${ }^{5}$ Figure 6.1: author's calculations based on data from The Maddison Project, http://www.ggdc.net/ maddison/maddison-project/home.htm, 2013 version. The long-term average growth rate is the compound growth-rate found when interpolating the development from 1900 to 2000. The data refer to GDP per capita in 1900 International Geary-Khamis dollars, implying that they are adjusted for inflation and based on purchasing power parity. The 12 Western European countries included in the sample are Austria, Belgium, Denmark, Finland, France, Germany, Italy, the Netherlands, Norway, Sweden, Switzerland and the UK.
} 
25

12 leading countries in Western Europe

20

... Long-term average $(1.87 \%)$

15

10

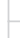

0

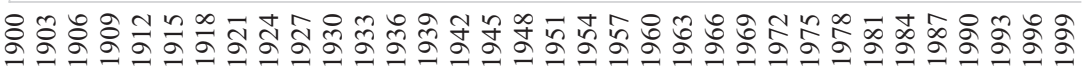

Fig. 6.1 GDP per capita, long-term trend and actual development (1000 1990 Int.\$), 1900-2000. (Source: The Maddison Project, see footnote for details)

ally-is the rate at which the economy would increase if there were no fluctuations and the values for 1900 and 2000 were fixed. The solid line shows the actual growth of GDP per capita. The difference between the two lines at a given point in time shows the degree to which the development thus far had deviated from the long-term trend.

At the start of the First World War, the income level in Western Europe was around 6.6 per cent lower than "predicted," but when the war ended this gap had increased to more than 28 per cent. After large fluctuations in the interwar period, the gap was reduced slightly by the outbreak of the Second World War, before plummeting to almost 47 per cent in 1946. In other words-GDP per capita after the end of the Second World War was only slightly more than half of what we "would expect" based on the long-term growth rates.

The destruction of two wars and the economic turbulence of the interwar period left Western Europe with an enormous "catching-up" potential. During the period in which this potential was fulfilled, the countries went through a period where living standards and production grew at an unprecedented pace. By 1973 the income level was more or less back on track, having grown almost 4.25 per cent annually. After 1973 the economic growth fluctuated around the long-term trend; a return to normal 
conditions implied that it would be difficult to repeat the spectacular growth spurt seen in the first post-war decades.

The first decades after the end of the Second World War are frequently referred to as "the Golden Age" in Western Europe and Japan; the Germans had their Wirtschaftswunder, the French had their Les Trente Glorieuses, and the Japanese their "economic miracle." Only the British remained in the quagmire of low economic growth. What can account for the exceptionally high economic growth in Western Europe in the first decades after the war?

The production possibilities in the middle of the 1940s were severely affected by the war damage. As seen in Fig. 6.1 the European GDP per capita was substantially below its "potential." The destruction of buildings and production capital and the fact that markets for labour, capital goods and services did not function well, meant that production was inefficient. From the late 1940s onwards, Western Europe was like a talented athlete coming back from a long-term injury-so progress was likely to be swift and sustained. As new technologies and organizational methods were introduced and markets were revitalized, higher efficiency followed. In most Western European countries productivity improvements were the main driver behind the high growth. ${ }^{6}$

These productivity improvements were also related to the rebuilding of the international economy. Governments in the leading industrialized countries were willing to go far to avoid a repetition of the dangerous economic nationalism and "beggar-thy-neighbour" policies that had created problems in the 1920s and 1930s and ultimately paved the way for the Second World War. The means to avoid such problems was an institutionalized world economy. With the United States in the lead, a liberal economic world order was established, built around policies and institutions that fostered collaboration and joint support. ${ }^{7}$ Multilateral

\footnotetext{
${ }^{6}$ See for instance the analyses in Temin (1997) or van der Wee (1986).

${ }^{7}$ This is of course only one side of the story; the Western one. An important element is the Communist counterpart-The Warzaw Pact, The Council for Mutual Economic Assistance, and so on. The policies in the Soviet Union and its Eastern European satellites turned out to be an unsuccessful_even disastrous-experiment in the long term. However, the Eastern Bloc and its Cold War threats were an extremely important catalyst for the integration in Western Europe and the capitalist world.
} 
institutions such as the International Monetary Fund (macro-economic policies), the International Bank for Reconstruction and Development (aid) and the General Agreement on Tariffs and Trade (trade policy liberalization) were established to oversee the smooth functioning of the international economy. Moreover, the European Recovery Program, usually referred to as Marshall Aid, kick-started a period of rapid and sustained improvement of incomes and living standards in Europe.

The period from 1950 to 1973 was characterized by high-and extremely stable - economic growth rates. In a situation with controlled inflation and low unemployment, Western Europe was one centre of growth in the world economy; the other was East and Southeast Asia, where the Japanese economic miracle of the 1950s and 1960s was followed by a handful of other "miracles" that focused on export-led growth and managed to mobilize resources on an impressive scale.

The strong growth of Japanese manufacturing affected shipping in two ways. First, Japan influenced transport demand: it imported the majority of raw materials used in manufacturing, which was then exported as finished goods-all the while needing shipping space. Estimates suggest that in the late 1960s Japanese demand made up 75 per cent of world coal transport, 60 per cent of iron ore transport and 20 per cent of grain transport. ${ }^{8}$ Second, the expansion of shipbuilding was an important ingredient in Japanese industrialization. In 1956 Japan surpassed the UK as the world's leading shipbuilder, and by the early 1970s more than half of the world's ships were built in Japan. ${ }^{9}$ The Japanese expansion within manufacturing pushed up the demand for shipping, and at the same time the Japanese built the ships needed to satisfy this demand.

In the first post-war decades world trade increased substantially. Trade liberalization was complemented by productivity-induced reductions in seaborne transport costs. Trade growth is of course extremely positive for shipowners. However, in addition to the volume of trade, the means of

\footnotetext{
${ }^{8}$ Alderton $(1973,78)$ quoted in Fon (1995a, 134).

${ }^{9}$ See Murphy (2013) for an introduction to the spectacular British decline. Shipbuilders in the UK were closely related to the domestic shipping industry. Among their foreign customers, the Norwegians stood out, but the ships provided by British yards were increasingly mismatched with the demands of the Norwegian owners. The British loss of the Norwegian market is discussed in Johnman and Murphy (1998).
} 
transport and the development of average distances is important-and both developed positively from a shipping point of view. Another important shift was the increasing reliance on oil as a source of energy and as an input in manufacturing. The strong growth in the transport of oil-the vast majority of which was seaborne-resulted in a transformation of the world fleet, where tankers became much more important.

In the second half of the 1960s the increasing demand for seaborne trade was further amplified by the longer average sailing distances after the 1967 closure of the Suez Canal. When the oil tankers to and from the Persian Gulf were forced to go around the Cape of Good Hope, average distances increased. Rather than a 6000 mile, 36-day roundtrip via Suez, tankers going between the Persian Gulf and Europe were subject to a 12,000 mile, 60-day roundtrip. From 1966 to 1973, the length of the average voyage undertaken by crude oil tankers, increased by 40 per cent. ${ }^{10}$

There was a positive feedback loop between the development of shipping demand and supply. Trade liberalization and growing trade volumes lowered unit transport costs as they enabled the utilization of economies of scale. At the same time, the lower unit costs led to a reduction of freight rates, thus reducing transaction costs and encouraging further growth in exports and imports. This development had implications for shipping, and also for the manner in which shipping services were produced.

Once again, Norwegian shipping could grow on the back of a rapidly expanding international economy, just like it had done in the second half of the 19th century. The adaptation to the international market was, however, diametrically opposite of the profitable strategy in the previous century. Then, low-paid sailors operated relatively cheap, old-fashioned and inferior ships financed by a limited Norwegian capital base. In the 1950 s, and particularly in the 1960s, high-cost Norwegian seafarers operated one of the most modern and expensive fleets, where the labour-cost disadvantage had been neutralized by means of economies of scale and costly technological solutions.

\footnotetext{
${ }^{10}$ Average distance growth calculated on the basis of Tables 1 and 2 in Fearnley \& Eger Chartering Co.'s Review, various issues. For a discussion of the geography of maritime trade, see Stopford (2009), Chapter 9 and Knowles (2006).
} 


\section{Technological Development After the Second World War}

Before we look more closely at the Norwegian experience, we should say something about the basis for the dramatic changes in the world fleet in the first post-war decades. The 1950s and 1960s were two decades of great innovative activity and rapid technological development. Shippers, shipowners, naval architects and shipyards worked together to revolutionize seaborne transport. The old "jacks of all trades" - the general cargo carriers-became increasingly unfashionable and were replaced by ships dedicated to the carriage of identical containers, or purpose-built vessels that carried large volumes of the major cargoes.

Innovations are often introduced as a response to bottlenecks in the production process, but usually end up creating new bottlenecks at other stages - the see-saw process between spinning and weaving in the 19th century textile industry is a typical example. In shipping, technological improvements have taken place within a complex framework, where at least four dimensions have to be considered before innovations can be introduced; the trade, the ship, the port and the inland infrastructure.

The basis for practically all international seaborne transport is trade. Countries trade because of price differences, arising as a result of resource endowments or variations in production costs or demand. Large price differences imply that trade leads to substantial benefits. Consider the value of spices in 15th century Europe relative to their price in the East Indies: the potential profits were so enormous that even the highly dangerous sea voyage - with the loss of the ship a very likely outcomemade economic sense.

Tariff reductions and the spread of manufacturing production provided a substantial increase in the benefits from international trade. From a shipping point of view, an important aspect of the development was the fact that the fastest-growing segment was commodities with a high volume or weight relative to their value-oil, iron ore, coal and grain.

Shipping demand is not only determined by the type of cargo, but also by the volumes that are traded. A crucial concept in the development of seaborne transport is the idea of "parcel size" - the typical size of the 
individual quantities that are transported. The parcel size depends both on the type of cargo and the destination; the need for iron ore at a giant Japanese steel factory is for instance much larger than the demand for sugar in a mid-size village. This difference will be reflected in the parcel size, which affects the choice of the "optimal" ship for a specific trade—or whether sea transport is suitable at all.

If there is potential for seaborne transport, the next question will be related to the ship itself. What are the restrictions with regard to size, storage, cargo handling, and so on? A bigger ship usually has lower unit costs, but one that is too large relative to the parcel size becomes uneconomical. The shift from sail to steam was hailed as revolutionary, as it enabled scheduled services and improved safety. However, in a long-term perspective, the shift from wood to iron and then steel as a building material was extremely important as well. The productivity improvement in world shipping has not been driven by faster ships, but primarily by larger vessels-physical size has been more important than speed. ${ }^{11} \mathrm{~A}$ simple thought experiment might illustrate the enormous size increases. Today, there are container ships with a length of around 400 metres. It takes around four minutes to walk from bow to stern. Picture a ship this size made out of wood, sailing in rough seas. The term "floating coffins"-favoured by both Samuel Plimsoll and Henrik Ibsen to describe the unseaworthy ships of the late 19th century-would take on new dimensions. ${ }^{12}$

\footnotetext{
${ }^{11}$ See Kaukiainen $(2006,2012)$. The improvements in carrying capacity have been spectacular: the largest bulk carriers today may hold more than 200 times as much cargo as the typical sailing ship of the late 19th century. Speed-wise, however, the improvement is more meagre; with 14 relative to 4 knots, the modern vessel is around four times faster (on days where there is decent wind).

${ }^{12}$ The size limit of wooden ships is partly related to limits in their building material, but surprisingly large wooden vessels have been constructed. In the first part of the 19th century sailing ships of around 90 metres were built, and the motivation for the design was one of the ever-recurring themes of human nature: tax avoidance. The Columbus and the Baron of Renfrew were so-called "disposable ships," built for one-off journeys from North America to the UK, where they would be dismantled and the timber sold - thus avoiding timber duties. Built in the middle of the 1820 s and around 10 times larger than the regular timber vessels at the time, the aim was not "sailing efficiency, but merely $[\ldots]$ getting the largest amount of timber across the Atlantic with the smallest possible expenditure," according to Williams $(1968,378)$. The Columbus became something of an attraction when berthed in London, while the Baron of Renfrew broke up into three main pieces outside France and provided a lot of free timber for beachcombers over the following years. A decline in freight rates and timber prices, as well as subsequent relaxation of timber duties, implied
} 
The post-war decades saw a technological improvement that some have claimed had the same far-reaching effects as the transition from sail to steam. ${ }^{13}$ While such comparisons are difficult, there is no doubt that the world fleet in the early 1970s was dramatically different from what it had been just a couple of decades earlier. One difference was size: improvements in ship construction-in particular the introduction of welding and new steel types_-enabled the building of bigger ships. The average ship in the world fleet in 1948 was around 2700 tons, while it was more than 5000 gross register tons (grt) in $1973 .{ }^{14}$ Given that the number of ships almost doubled, and their capacity, speed and turnaround time increased as well, the carrying capacity of the world fleet increased by a factor of more than four.

The average size of the ships increased, but for specific types of vessels, the largest ships became much, much larger. The use of economies of scale was particularly strong in certain trades, for instance in the tanker market. In the early 1920s Esso built 22,000 dead weight ton (dwt) tankers, which remained the world's largest for the next 25 years. The biggest tanker in 1950, the SS Velutina, was slightly less than 30,000 dwt. Ten years later, the Universe Apollo was four times larger, and the Universe Ireland, delivered in 1968, was more than 10 times larger. ${ }^{15}$

The increasing ship sizes posed some challenges, not only in port, but also at sea. Large ships are more difficult to navigate and control. Changing the course takes more time, and the "braking distance" for a 200,000 dwt ship at full speed is 4 kilometres, even after reversing to "full astern." The distance needed to stop would increase to an amazing 10 kilometres if the wind, currents, and so on were unfavourable. ${ }^{16}$ Moreover, if there is an accident, the environmental impact of a large ship-with a giant cargo and a huge store of bunkers-would be worse than for a

that no more disposable ships were built for this trade. The largest wooden ship built- the sixmasted, 3700 gross ton Wyoming, built in 1909-illustrates the problems of using "live" wood as a building material on giant vessels. Even though the ship — which at 329.5 feet just pipped the 100metre line-had been stiffened with steel, the Wyoming bent and twisted in bad seas and in 1924 sank with 13 lives lost.

${ }^{13}$ Mayer (1973, 145).

${ }^{14}$ Calculated on the basis of Lloyds Register of Shipping Statistical Tables, 1980, 75.

${ }^{15}$ See the overview of the growth in average and maximum sizes in Stopford $(2009,40)$.

${ }^{16}$ Dahl $(1970,31)$. 
smaller ship. When the Sinclair Petrolore exploded in 1960, the oil spill60 million litres-was more than twice as large as anything seen before. ${ }^{17}$ Still, the benefits related to economies of scale, and improvements in shipbuilding, navigation and safety, led to a strong increase in average and maximum sizes.

Size increases were important, but there were also fundamental changes in the composition of the fleet. A number of new ship types were introduced. The 1950s and 1960s saw a massive decline in the proportion of general cargo carriers, and a substantial increase in the share of tankers, bulk carriers and specialized ships. Innovations made the transport of traditional commodities cheaper and more efficient, and also enabled the large-scale transport of cargoes that had previously been too difficult or dangerous to carry on a ship.

The new vessel types-combination carriers, container ships, gas tankers, chemical parcel tankers and car carriers among others-ensured a much greater variety in the types of vessels that made up the world merchant marine. A rapidly growing number and volume of commodities were carried "in bulk" - directly in the hold of the ship, rather than in any kind of packaging. In the first post-war decades, the world fleet became far more specialized-a process that the maritime economist, Martin Stopford, has referred to as "shipping's industrial revolution." 18

If the first two elements - the trade and the ship —are in place, the next bottleneck will be the port. At some point economies of scale turn into diseconomies of scale. Increasing the ship might reduce the unit costs at sea substantially, but if the vessel spends five weeks in port to be loaded and another five weeks to be emptied, the net benefit might be negative. Bigger is not always better. Consequently, efficiency improvements at sea are futile, if they are not followed up by new solutions in port.

\footnotetext{
${ }^{17}$ Devanney (2006, 23-27). The Sinclair Petrolore had been the world's largest ship when delivered in 1955. Just like size records were broken, the oil spill record did not last long. In 1967 the Torrey Canyon was grounded after a navigational error, when the captain tried to take a shortcut in order to reach the tide at the Milford Haven terminal in Wales. The Torrey Canyon accident paved the way for stricter regulation, including the introduction of the International Convention for the Prevention of Pollution from Ships. The ship also entered pop culture, through an eponymous song by French crooner Serge Gainsbourg, with the catchy refrain "cent vingt mille tonnes de pétrole brut" -120 thousand tons of crude oil.
}

${ }^{18}$ Stopford (2009, 39-46). 
Shipping innovations must be matched by improvements on land to make them profitable. The Vaderland, built in the UK in 1872 for the Belgian Red Star Line, was the first steamer designed for the international transport of petroleum in bulk. However, neither the United States nor the Belgian authorities liked the idea of combining flammable petroleum and passengers, even on different legs, and the quayside facilities were inadequate. Consequently, on its first return trip from the United States, Vaderland carried general cargo in its tanks, and there is no record of the ship actually performing the bulk petroleum transport for which it was designed. ${ }^{19}$

The technological transformations-from sail to steam to diesel before the war, and improvements in vessel size and specifications after the war-have all reduced the labour intensity of the "shipping" leg of seaborne transport. The sailors have climbed down from the crow's nest and the rigging and the firemen and stokers have left the boiler room. However, even in the first post-war decades, what happened in port-the interface between the sea and the land-was relatively labour intensive, particularly for general cargoes. The large European ports, for instance Antwerp and Rotterdam, relied on large pools of casual labour, dockworkers who cherished the freedom to decide how much they would work and for whom. ${ }^{20}$

The new ships required changes. Although the first super-tankers were loaded at special offshore terminals and had to discharge part of their cargoes to smaller ships in outer bays before they could proceed to the port, the economies of scale involved when the ship was at sea were so large that transhipment still made sense. ${ }^{21}$ In time, the ports developed in a manner that made it possible to accommodate the new ship technologies. There was a constant focus on improving the speed of loading and unloading, and the construction of dedicated onshore terminals proved to be a solution for many commodities.

Finally, in order to fully utilize the new advances, it is necessary to be able to transport the cargoes efficiently to their final inland destination.

\footnotetext{
${ }^{19}$ Dunn (1956, 20-21).

${ }^{20}$ Vanfraechem $(2012,150)$.

${ }^{21}$ Young $(1971,20)$.
} 
This infrastructure-that stretches the ocean into the Hinterland-is sometimes forgotten. However, efficient transfer to subsequent means of transport_-pipelines, barges, feeder ships, trains or trucks-is necessary in order to fully utilize the advantages of innovations in ships and ports.

\section{Three Technological Revolutions: Containerization, Bulkification and Specialization}

In the post-war period, three technological concepts have managed to combine all the four critical features above - the trade, the ship, the port and the inland infrastructure. The result has been three related technological development traits-containerization, bulkification and specialization - that have all been bolstered by the more general utilization of "economies of scale" in ship construction and in transport. Together, these developments revolutionized seaborne transport in the decades after the Second World War.

The most visible of these trends, at least in daily life, is containerization. In many ways, the ubiquitous containers-usually emblazoned with the logo of one of the large liner companies- Maersk, Evergreen, Hanjin, CMA CGM-have become one of the foremost symbols of globalization. While the average liner had spent only one day at sea for every four days in port, this changed to only one day in port for every day at sea for the container vessels. ${ }^{22}$ As ships make money when they transport goods, not when they are in port, the effects on prices, profits and productivity were overwhelming.

The theoretical basis for containerization was standardization-the fact that identical units make storage, movement and planning much easier. Before containerization, managing the consignments on general

\footnotetext{
${ }^{22}$ Vanfraechem $(2012,152)$. Compared with previous centuries, the transport revolution is even more striking. Efficient container terminals can move around 300 containers from a vessel in one hour-amounting to a conservative 3000 net register tons. These containers would fill one of the large sailing ships of the late 19th century-ships that typically had a turn-around time in port of around a month or more; see for instance Sager and Panting $(1990,141)$. A couple of hours versus one month makes a lot of difference in an industry where time is money.
} 
cargo carriers often provided the deck officers with a logistical nightmare, where legal, safety and practical issues posed a lot of challenges. A classic example was the US ship SS Warrior, which in the middle of the 1950s was subject to one of the first detailed productivity studies within shipping. On a voyage from New York to Bremerhaven, the vessel carried a total of 74,903 cases, 71,276 cartons, 24,036 bags, 53 wheeled vehicles, 22,339 individual pieces in 10 other categories (barrels, reels, etc.), in addition to 1525 units simply identified as "undetermined." ${ }^{23}$ All of this had to be stowed securely and accessibly, and the complexity of course spilled over onto the land side.

Ports were characterized by "intense activity dockside. Sacks, boxes, crates - goods of all shapes and sizes - would be laid out in a seemingly disordered fashion, among which dozens of men swarmed carrying out different tasks." 24 The shipping container brought order into this chaos.

The box also brought other benefits. Containerization reduced cargo claims due to damage and pilferage (the proportion of goods that "fell off the back of a lorry" was reduced significantly with containerization). It also enhanced safety. In the mid-1950s half of all longshoremen were injured on the job annually, and one out of six suffered a disabling injury, according to one US study. ${ }^{25}$ Containerization reduced accidents and made the dock workers' jobs safer, on a daily basis. In the longer term, the mechanization of course made the job itself insecure-the technology needed fewer, but more skilled workers.

Like most innovations, containerization had a relatively slow start. The US trucker Malcom McLean is credited with the "invention" of the concept, and the inception is dated to 1956 and a trip from New Jersey to Puerto Rico by the ship Ideal $X$, but container sizes and transport

\footnotetext{
${ }^{23}$ The study of the SS Warrior's 10-day trip in March 1954 is frequently used as an example of the complexity; Levinson (2006a). While most sources refer to the Tayloresque productivity studies, the aim was to optimize aspects such as navigation as well; see Allen (1954).

${ }^{24}$ Vigarié (1999, 4); see also Donovan (1999).

${ }^{25}$ National Research Council $(1956,1)$, from a study of more than 7000 work accidents on the US Pacific Coast in 1954. Among longshoremen there were 92 disabling injuries per million man hours worked-almost eight times as much as in manufacturing in general. The worst place to work was in the hold, where more than half of all the accidents took place, with another 15 per cent occurring on the deck of the ship; National Research Council $(1956,71)$.
} 
concepts varied for decades after this. ${ }^{26}$ As the use of containers increased, up to the point where it had become the dominant technology, work on the docks changed tremendously. Moreover, in many countries the port infrastructure was also transformed, with liberalization, privatization and deregulation complementing the new technological possibilities.

Containerization had a particularly large effect on the transport of finished goods. ${ }^{27}$ However, efficiency improvements in shipping also led to a drastic reduction in the cost of moving inputs. The transport of commodities was revolutionized by the utilization of the bulk concept and the introduction of specialized ships that either enabled the transport of new products, or drastically reduced the cost of transporting commodities that had previously been moved by general cargo carriers. Although they are largely absent from the container sector, within bulk and specialized shipping, Norwegian companies were among the pioneers.

The term "liquid bulk" is used to characterize tanker shipping. The dry bulk concept-referring to the manner in which loose commodities were carried directly in the hold of the ship, rather than being individually packaged - actually pre-dated tanker shipping, though at the start of the 1950s it was much less important. The collier (coal ship) John Bowes, a hybrid steam/sailing ship built in 1852, is often credited with being the first modern bulk ship. In North America "whalebacks," bulk carriers that have been likened "to a floating cigar with ends upturned," were common on the Great Lakes from the 1890s and well into the post-war period. ${ }^{28}$

In the 1950 s and the 1960 s, dry bulk shipping became an important activity in the intercontinental market. The combination of longer distances between source and destination for some of the most important commodities, as well as increased volumes, made the bulk concept much more attractive than conventional general cargo ships with several

\footnotetext{
${ }^{26}$ See Levinson (2006b), which gives a good presentation of the history of container shipping or the more condensed Levinson (2006a), which focuses on the port of New York. See Poulsen (2007, 2010) for a presentation of the Scandinavian response to containerization, and Bakka (2008), for a discussion of the impact on Norwegian liner shipping.

${ }^{27}$ When the major South Korean container operator Hanjin Shipping filed for bankruptcy in the autumn of 2016, the company was accused of "spoiling Christmas"; Cooper (2016).

${ }^{28}$ Dunphy (1979, 351).
} 
individual decks in the hold. Bulkification was a key ingredient in the spread of manufacturing production. The major market for the dry bulk ships was intercontinental trade of coal, iron ore and grain. ${ }^{29}$

Minor dry bulk goods — steel and forest products, bauxite, alumina and a number of agricultural goods-were transported in specialized ships, reflecting the smaller parcel sizes in these trades. But bulk-like concepts are also behind, for instance, LNG- and LPG-tankers, ships carrying liquid natural gas and liquid petroleum gas, respectively. While such gases had previously been carried in small, individually pressurized tanks, in the 1950s and 1960s purpose-built ships with large tanks, combining pressure and refrigeration, were introduced.

A similar innovation was chemical carriers, often referred to as "parcel tankers." Here, the combination of different parcels on the same ship enabled the use of bulk storage and transport even for smaller volumes. The parcels could be different chemicals, consignments owned by different customers, or cargoes that were coming to or going from different ports. The parcels would typically be too small to justify the chartering of a full ship, but sufficiently large to make individual packaging inconvenient and inefficient. Dedicated ro-ro (roll on-roll off) ships were also built to transport cars and other vehicles, and ships were purpose-built for the carrying of livestock or heavy and bulky cargoes.

The development of the specialized ships implied that there was a large number of new efficient competitors that challenged the position of the old general cargo carriers - the traditional ships that were suitable for almost all cargoes, but well-suited for almost none. Specialization had dramatic effects on the cost of transport; freight rates fell by 50 per cent or more, at the same time as the shipping companies' managed to increase their own profits substantially. ${ }^{30}$

In some market segments, the main competition was not new ship types, but other means of transport. The airline industry more or less killed off intercontinental passenger transport in the 1960s. Norwegian

\footnotetext{
${ }^{29}$ With regard to grain, the dry bulk ships also competed with tankers. Properly cleaned oil tankers were used for grain transport if the crude oil market was poor, and even for grain storage if the crude oil market was terrible.

${ }^{30}$ See the example of transport costs for chemicals between the United States and Japan in Murphy and Tenold $(2008,294)$.
} 
shipping companies had never played a big role in that market-with the exception of the domestically based Den Norske Amerikalinje, whose home market was protected. The company's trans-Atlantic activity peaked in 1956, with some 25,000 passengers. ${ }^{31}$ Gradually, the company entered the cruise market, one of the many markets that became a "Norwegian specialty" in one of the most expansive periods of Norwegian shipping.

\section{Norwegian Fleet Expansion}

As mentioned in Chap. 2, the expansion of the Norwegian fleet in the 1950s and 1960s was tremendous - the size of the fleet doubled in the 1950 s and doubled again in the 1960s. Moreover, the growth was very well adapted to the structural changes in shipping demand. Norwegian owners were at the forefront of the technological development, focusing on two of the three main technological breakthroughs-bulkification and specialization.

The Norwegian owners already had a flying start with regard to bulkification, as a result of their position as the world's largest independent tanker owners. The strong involvement in tanker shipping continued in this period, but the Norwegians were also among the pioneers in the transport of dry bulk goods, with an average market share of 18.7 per cent of the world fleet during the 1960s. The market was dominated by ships registered in Japan, Norway, the UK and (by proxy) Liberia. ${ }^{32}$

Anders Martin Fon, who has written the most authoritative history of Norwegian post-war dry bulk shipping, points out that Norway's leading position in the 1950s and 1960s was the result of the shipowners' openness towards new ideas. An entrepreneurial and creative spirit characterized the owners, both in the early days of dry bulk vessels in the 1950s, and when the trade was increasingly supplemented by combination

\footnotetext{
${ }^{31}$ See Vea, Seland and Schreiner (1960) and Bakka (2008).

${ }^{32}$ Market share calculated on the basis of Fon (1995a, 293). The ownership of the Liberian fleet was divided among several countries; in the beginning of the 1970s around half the fleet was owned by Greek interests, a third by Americans and the rest by shipping companies from various other countries.
} 
carriers_-ships that could transport both wet and dry bulk cargoes—in the 1960 s. $^{33}$

Regardless of the leading Norwegian position within dry and liquid bulk shipping, the real Norwegian "specialty" was specialized ships. Developments during the 1950s and, in particular, the 1960s, had an impressive effect on the Norwegian share of a handful of specialized shipping segments. In many of the new market segments, Norwegian shipping companies, brokers, ship equipment producers and naval architects played key roles in the development of the new technology. They were instrumental in the introduction or improvement of new ship types, and they also introduced novel ways in which ships could be owned, operated and managed. New types of charter contracts, joint ownership of vessels and pool operation enabled Norwegian shipping companies to build up a substantial presence in many of the new segments, in particular the intercontinental transport of chemicals, gases and forest products.

By the beginning of the 1970s, three of the four largest companies in the chemical tanker market had their roots in Norway. More than 30 Norwegian companies were involved in gas transport, owning around 17 per cent of the world fleet. In Bergen, two competing shipping pools were building up the world's largest fleets of open hatch bulk carriersships that were especially suited for the transport of forest productscontrolling almost two-thirds of the market by the middle of the decade. ${ }^{34}$

Why did Norwegian shipping companies succeed so well in the development of specialized shipping niches? At least three factors were at play. First, the Norwegians had excellent market knowledge. Their long history and close relationship to major customers implied that they were able to spot opportunities and gather the information necessary to implement new technologies. Many of the new specialized segments could be put in the bracket "industrial shipping," where new contract types and close cooperation between customers and shipowners characterized the business. Long-term contracts of affreightment, where the shipper promised cargo volumes and the shipping company promised transport capacity, often formed the basis for investments in new tonnage.

\footnotetext{
${ }^{33}$ Fon (1995a, 195-235); see also Fon (1995b).

${ }^{34}$ Tenold (2015a, 105-108).
} 
Second, in the period where the Norwegian shipping companies introduced their new technological solutions, shipbuilding was still an important Norwegian industry, and several of the new or refined ship types were designed by Norwegian naval architects and built at Norwegian shipyards. An example is LNG-shipping, where the research arm of the classification society Det norske Veritas was engaged to refine a concept that Hans Ludvig Lorentzen, the oldest son of the shipowner Øivind Lorentzen, had developed. The first ship based on Lorentzen's patented sphere design, Mundogas Brasilia, was delivered in 1961—built in Norway and owned by a Lorentzen company. ${ }^{35}$ In the longer term, other auxiliary entities-naval architects, consultants, brokers, equipment manufacturers-provided important input into the design of the technology and the development of the service.

Finally, there was room for trial and error in Norwegian shipping. The tax system made investments in new shipping capacity very profitable. The specialized ships carried some risk, but potentially large benefits as well. In a number of cases, innovative entrepreneurs worked together with older, wealthy companies to invest in the new technology. This implied that resourceful individuals with limited means could benefit from the existence of older companies with available funds - and vice versa.

In the 1950 s and 1960 s the Norwegian shipping industry was propelled forwards by a two-pronged strategy, utilizing two of the technological concepts. On the one hand, there was bulkification. The massive investments in crude oil tankers, dry bulk ships and combination carriers weighed heavily in tonnage terms, and are the main explanation of the fact that Norway's share of the world fleet increased from around 6 per cent in the late 1940s to a record-breaking 10 per cent two decades later. On the other hand, there was specialization: investments in smaller, specialized ships, often innovative vessels that created their own new markets. Both of these strategic paths depended upon developments abroad, but were forcefully shaped by conditions at home. The Norwegian strategies were determined by the domestic access to labour and capital, influenced by economic policies in general, and shipping policies in particular.

${ }^{35}$ Bakka (2017, 97-99). 


\section{Shipping Policy and Factor Costs}

In 1967, David Vikøren, Director of the Norwegian Shipowners' Association, gave a presentation called "Merchant Marine Policy of Norway" at a Canadian conference. His presentation suggested that the Norwegian shipping policy at the time was one of minimal interference and preferences - at least of the positive, subsidizing kind. Instead, he claimed that "Norwegian shipping is taxed harder than in most other countries, is subject to stricter manning rules" and was at a disadvantage with regard to technical standards, safety requirements, education and research. Quoting Sturmey's classic book about the decline of British shipping, he concluded that "Norwegian shipping expanded in spite of, not because of, the actions of the government." 36

Given these alleged internal restrictions, the fact that Norwegian shipping managed to remain competitive and increase its share of the world fleet in the first post-war decades may seem surprising. However, as any airport strategy book will tell you, business is all about adapting to the circumstances, rising to the occasion and laughing in the face of adversity. Thus, Vikøren's negative spin on the authorities' influence should not be accepted unconditionally. The authorities did indeed influence the industry, but for much of the 1950s and 1960s the influence consisted of "nudging" the strategies of the shipping companies. And inadvertently, most shipowners were nudged in the right direction. ${ }^{37}$ With the exception of the contracting ban at the very start of the period, the policies did not hold back their business activities, they just shaped the decisions that shipping companies made. And up until 1973, the shipping and economic policies in Norway encouraged shipping companies to make some very wise moves. ${ }^{38}$

\footnotetext{
${ }^{36}$ Vikøren (1967, 8-9).

${ }^{37}$ Here it is important to point out that we are not talking about conscious industrial policy, in the sense that the authorities had the ability to pick winners or forced shipowners to follow a predetermined strategic pattern. Rather, the main priority of the policies was to fulfil other goals, in particular regarding employment, tax revenue and balance in Norway's external economic relations. The beneficial strategies became an accidental by-product of the regulations.

${ }^{38}$ Two good analyses of the Norwegian shipping policies in the 1950 s and early 1960s are Svendsen (1957, 1964).
} 
A case in point is the manner in which the policies influenced the expansion of the fleet. In his analysis of the effects of the tax regime in the interwar period, Eivind Merok has pointed out that the political economy of Norwegian shipping was "highly beneficial for entrepreneurs willing to make bold investments in larger, more expensive vessels, leveraging their investments heavily and betting on future asset prices to generate extraordinary profits." ${ }^{39}$ This description fits the situation after the Second World War perfectly, as well.

The Norwegian shipping companies expanded at an impressive rate in the 1950s and 1960s, on average increasing their fleet by almost 7 per cent annually. At the international level, the situation may appear similar to that of the interwar period, when Norway gained market share at the expense of other countries. However, at that time, the Norwegian fleet grew while the world fleet stagnated or declined. In the first post-war decades, Norway gained substantial market share in a market that was growing rapidly.

\section{Sources of Capital}

The Norwegian fleet expansion was based on large, expensive vessels and novel technological solutions. Two questions are particularly interesting in this respect. First, how was it possible to finance this extreme growth? Second, how were the investment decisions, including decisions about the level of total investment and the choice of investment objects, affected by the government's policies?

In general, Norwegian shipping companies had three main sources of capital; retained earnings, domestic equity and loans from domestic and foreign sources. All three were affected by the authorities' policies.

With regard to retained earnings, the authorities encouraged companies to keep profits within the company, rather than paying it out to the owners. From 1953 onwards, domestic regulations limited dividends to a

${ }^{39}$ See Merok (2011). 
maximum of 5 per cent of the share capital. ${ }^{40}$ This restriction had two aims. The first was to keep funds within the company in order to enable investments in new production capacity-in the case of shipping companies: new tonnage. Second, the limitation of the dividends was intended to "regulate the income" available to capitalists, a feature that was also seen in limitations on the salaries of management and the remuneration of company directors. ${ }^{41}$ In the ever-present discourse between the market and the authorities - between the invisible hand and the visible handthe Norwegian system was leaning quite heavily towards state intervention in the first post-war decades.

The design of the Norwegian tax regime also encouraged the reinvestment of profits. Indeed, the tax system almost made the limitations on dividends superfluous; the manner in which dividend payments were taxed-first with respect to the company, then with respect to the shareholder-made them almost prohibitive. ${ }^{42}$ The shipping companies' tax rate was high - in the period 1946-1958 income and wealth taxes amounted to almost two-thirds of their taxable income. Furthermore, as the marginal tax rate on dividends could exceed 100 per cent for some individuals, it is evident that it would be better to reinvest profits in new tonnage that gave substantial tax deductions. ${ }^{43}$

The tax system led to a pro-cyclical pattern in the contracting of newbuildings — in years when the market was good, and profits were high, the pecuniary benefits of investing in ships, rather than paying tax, were particularly high. Finally, the double taxation implied that money remained in existing companies, rather than being made available for new investment projects. The tax system consequently had a preserving effect on the industrial structure - policy-induced path dependence. As a lot of money

\footnotetext{
${ }^{40}$ Søilen $(1998,111)$. It was possible to apply for a dispensation from this rule, and some companies were allowed to pay out more when the market was particularly beneficial. There was also a tendency for the rules to be interpreted more leniently towards the end of the 1950s; see Gjermoe (1968, 50-52; 1972, 49-54).

${ }^{41}$ From a speech by Minister of Finance, Erik Brofoss; Norway, Parliament, Stortingstidende (1945-1946), 233-246.

${ }^{42}$ Aars-Nicolaysen $(1959,27)$. By 1959 the maximum limit had increased to 6 per cent; see also Damman (1958).

${ }^{43}$ Seland $(1960,10-11)$; typically, the marginal tax rate for wealthy share owners would be in the region $60-80$ per cent.
} 
was invested in shipping, a lot of money would remain invested in shipping.

The second source that financed the fleet expansion was equity raised in the Norwegian market. It is very important to keep in mind that the 1950s and 1960 were a period with very limited possibilities for crossborder investment. Due to restrictions on capital movements-mainly introduced in order to keep exchange rates stable-Norwegian funds were to a large extent "locked in" within the country. Again, the "traditional Norwegian predicament" - that alternative investments did not provide particularly large profits — helped the shipping sector. ${ }^{44}$

The part ownership had managed to raise investment capital from quite a large proportion of society in the 19th century, partly as a result of the ability to contribute in kind, partly as a result of limited alternative placements. To which extent was this replicated in the second half of the 20th century-how common were ship investments?

In the early 1960s, the economist Eilif Gjermoe analysed the accounts of Norwegian shipping companies. Around 300 companies owned ships larger than 500 grt in 1963 . The main source on limited liability companies, Kierulfs Håndbok, gave information on 225 such companies within shipping and whaling, of which 119 were listed on the stock exchanges. In total, the stock exchange listed companies had more than 50,000 shareholders and an ordinary share capital of marginally more than NOK300 million. ${ }^{45}$ Only four of the companies had an ordinary share capital of more than NOK10 million, and another 14 had a share capital of between NOK5 million and NOK10 million. ${ }^{46}$

Despite the quite substantial number of shipping companies listed on the stock exchanges at this time, the role of the stock exchange as a source

\footnotetext{
${ }^{44}$ The basis for this low alternative return-limited resources and a thin market—continued to be relevant. However, in the post-war period energy-intensive manufacturing, utilizing Norwegian hydro power, became a profitable alternative that would compete with shipping for funds.

${ }^{45}$ There is some overlap between share owners. It is also likely that investments in the stock exchange-listed companies, which were relatively liquid and easy to buy and sell, was more widespread than for the remaining shipping companies.

${ }^{46}$ Gjermoe (1968, i-ii). Some shipping companies (rederier) were affiliated with more than one limited liability company (aksjeselskap), while others had different forms of incorporation. The companies included in the analysis on average made up more than one-third of the Norwegian fleet in the period 1946-1964; Gjermoe $(1968,11)$.
} 
of capital was quite limited. In the period 1965-1970, for instance, only NOK6.4 million worth of new capital was raised for shipping companies at Oslo Børs. These emissions — one in 1966 and one in 1970_-amounted to less than 1 per cent of fresh capital raised at the stock exchange. Typically, shipping company shares were "not recommended" as investment objects; their development in the 1960s had been "very meagre" and the liquidity of the shares was far from satisfactory. ${ }^{47}$

Finally, the Norwegian shipping companies had access to loan finance at home and abroad. In the first post-war decades the Norwegian authorities sanctioned a low interest rate policy in order to encourage investments. With such a policy, access to capital is not only determined by the borrowers' willingness to pay, but also by political preferences about how the queue for funding is organized and ordered. At the same time, there was an element of competition. In the words of Norway's Central Bank Director, Erik Brofoss, in 1959: "An important aspect of our investments is that $25-30 \%$ of the total gross investments are within shipping. It is evident that this industry is willing to pay a far higher interest rate than it would be possible to charge for instance agriculture." ${ }^{48}$

There were several domestic sources. In 1906 a consortium of four banks had established Norsk Skibs Hypothekbank AS, which aimed at providing first priority mortgages, but the terms were initially relatively strict. The war insurance arrangement introduced during the First World War was discontinued in 1923 with a NOK48 million profit. This was distributed to the Fund for Seamen (NOK20 million) and compensation for losses on maximum freights (NOK10 million), with most of the remainder going to establish a financing institution, Norsk Skipshypothek $A S$, in 1928, with headquarters at Minde, near Bergen. ${ }^{49}$

\footnotetext{
${ }^{47}$ Nyquist and Wiik $(1972,56-65)$. The 1 per cent of the new funds raised can be compared with the fact that shipping companies made up 45 per cent of the number of companies listed on Oslo Børs in 1971.

${ }^{48}$ Brofoss $(1959,32)$. This is the same Brofoss that was referred to earlier as Minister of Finance in the immediate post-war years. He also became the first head of Norway's Department of Trade and Shipping (1947-1954), a position he left to become Director of the Central Bank.

${ }^{49}$ Two smaller, differently organized, institutions also provided first priority mortgages. In 1916 Norges Skipshypotek Forening was established in Oslo, while Redernes Skibskreditforening was established by 14 shipowners on the South Coast in 1929; see Petersen (1979).
} 
A new source of finance, characteristic of the manner in which Norwegian economic development in the first post-war decades was determined at the crossroads of public policy and private institutions, was Laneinstituttet for skipsbyggeriene [the Mortgage Institute for the Shipyards]. Established in 1959, it was owned by the leading banks, shipyards and the Norwegian Shipowners' Association, but was provided with a loan from the Ministry of Finance and also given government guarantees. Låneinstituttet would only fund vessels built at Norwegian shipyards, and was aimed at helping Norwegian shipbuilding, rather than shipowners. ${ }^{50}$ However, given that Norwegian shipowners, partly as a result of the restrictions on their foreign activities, were by far the most important customers at Norwegian yards, there was a beneficial effect for shipping as well.

The Norwegian banks participated in the financing of Norwegian shipping through the cooperative institutions at home and abroad, but also on their own books. They cooperated to establish consortia in Zurich (1958) and Amsterdam (1968) to raise capital abroad for ship investment in Norway. Several banks had shipping as a specific strategic priority, and there were sometimes "revolving doors" between the banks, shipping companies and shipping institutions. ${ }^{51}$ The sheer amount of capital involved, and a desire to spread risk, implied that loans to shipping were often organized as syndicates, with the participation of both domestic and foreign banks.

Foreign banks and, in particular, foreign yards and their associated financing institutions, were eager to lend money to Norwegian shipping companies. According to a contemporary report, the shipping sector was responsible for between two-thirds and four-fifths of the private capital imported into Norway in the period 1958-1967. ${ }^{52}$ As such, the shipping companies were in a somewhat strange position, finance-wise.

\footnotetext{
${ }^{50}$ See Sejersted (1982) or Knutsen, Lange and Nordvik (1998) for an introduction to the banking side of this, and Platou and Stokke (1980), for a more general introduction. The cunning manner in which the Norwegian authorities managed to raise capital abroad-by depositing the country's currency reserves at terms that were below the market terms in banks that were willing to lend money for ship purchases-is discussed in Knutsen (1997).

${ }^{51}$ Sejersted $(1982,228)$.

${ }^{52}$ Boldt-Christmas, Fagerland Jacobsen and Tschoegl (2001, 82).
} 
For much of the first two post-war decades, government regulations stipulated that shipowners had to fully finance abroad newbuildings that they ordered from foreign yards, so as not to deplete the limited Norwegian reserves of foreign exchange. This implied that shipowners borrowed money abroad to invest, while at the same time were forced to keep their deposits in Norwegian banks at low interest rates. ${ }^{53}$ Although the demand for "currency neutrality" for ship investments implied that Norway formally flouted the rules of the Organization for European Economic Co-operation (OEEC), it was "understood and silently accepted" by the organization. ${ }^{54}$

The main reason for the shipping companies' easy access to financing abroad was expanding capacity in the shipbuilding industry. The Japanese shipyards were formidable challengers to the European hegemony, and the solution to ensuring orders was to provide easy-and often state-subsidized-financing. As a result of a race-to-the-bottom in shipbuilding subsidization, the Organization for Economic Co-operation and Development (OECD) in 1969 introduced an Understanding on Export Credits that stipulated the maximum indirect or direct support. ${ }^{55}$ According to the terms of the agreement, interest rates could not be lower than 6 per cent, the repayment period could not be longer than eight years, and financing could not exceed 80 per cent. The aim of the agreement was to increase real competition in the shipbuilding industry and neutralize support measures that had a distorting effect on competition among shipyards and among shipbuilding nations. At the time, the OECD-countries were responsible for around 90 per cent of new deliveries.

The analysis above has shown the many ways in which the authorities influenced the financing of shipping-both the type of investment, as well as the level and timing of investment. A similar influence was seen in connection with labour regulations. The legal framework played a

\footnotetext{
${ }^{53}$ Seland $(1959,43)$. This regulation was in force from 1947 to 1952 for general cargo carriers, but lasted until the early 1960s for tankers and most other specialized vessels. See also Nossum (1960). ${ }^{54}$ Statistics Norway $(1965,393)$.

${ }^{55}$ The OECD was the successor of the OEEC, established by the OECD declaration in 1960, between the OEEC countries (in practice "Western Europe" minus Finland), the United States and Canada. Japan joined in 1964 and Finland five years later.
} 
particularly important role for the choice of ship types. While there was relatively good access to capital, the labour situation was more difficult.

\section{Manning the Fleet}

Immediately after the war the question of manning the ships became problematic. ${ }^{56}$ Demand for workers onshore was substantial, and many of the seafarers that had kept the Norwegian merchant marine going during the war were still fighting their own battles, which made them illequipped to sail. The deficit of Norwegian seafarers could be supplemented by foreigners, but only up to a point, when Norwegian regulations would kick in. By 1967 around a quarter of the seamen on Norwegian ships were foreigners, mainly other Europeans that were employed on Norwegian terms. ${ }^{57}$ However, in the longer term the solution to the recruitment problem became rationalization and economies of scale.

One of the most fascinating transformations in shipping in the first post-war decades is the manner in which seaborne trade went from being a labour-intensive activity to becoming a high-technology, capitalintensive business. The Norwegian ships did become more technologically advanced and more expensive throughout the century, but in the first half of the 20th century there were no revolutions in the manner in which cargoes were handled and ships were operated. The number of seafarers per ship was relatively constant (although the ships became bigger) before the Second World War.

After the war, the number of seafarers per ship increased, before levelling out around 1960. The average tonnage per seafarer increased only marginally. During the 1960s, however, there was a break in the development. The amount of tonnage per seafarer accelerated as the average size

\footnotetext{
${ }^{56}$ Egeland (1971, 23-24). Norwegian seafarers sailing on foreign ships were even urged to sign on Norwegian vessels for patriotic reasons; Verdens Gang, 190347, 6.

${ }^{57}$ Seafarers' lives and organization have been documented in a series of recent publications. See Olstad (2006) for the period up to 1960, Halvorsen (2007) for seafarers in general, Halvorsen (2010) for the question of foreigners, and Koren (2017) for an overview of the welfare aspect. See also Tenold (2015b) for a broad overview, as well as the discussion of the "uncounted" foreigners in Chap. 8.
} 
of the Norwegian ships increased enormously. From the middle of the 1960 s there was also a decline in the number of seafarers per ship-even though the ships got bigger-as rationalizing measures were introduced. This trend towards economies of scale was much stronger in Norway than in other countries.

In 1955 the average Norwegian ship was marginally smaller than the average ship in the world fleet-the difference was 0.4 per cent. Five years later, the average Norwegian ship was 15 per cent larger than the average ship in the world fleet, by 1965 the difference was 49 per cent and by 1970 it was 59 per cent. At the peak, in the middle of the 1970s, the average Norwegian ship was more than 80 per cent larger than the average ship in the world fleet. ${ }^{58}$

This focus on large ships can be explained by the high and increasing labour costs. There were three main reasons that Norwegian labour costs increased more than those in other countries after the Second World War. The first is an above-average increase in Norwegian wage levels, as the Norwegian economy developed. The second is the relatively high manning requirements - the cabin conditions, the turn system and restrictions on working hours contributed to pushing up costs. In 1951 new manning regulations were introduced, which were particularly strict for smaller ships. The small Bergen tanker Rogn illustrates the effects of the law. The compulsory manning of the ship increased from 15 to 21 when the new regulations entered into force - a problem, given that the ship only had berths for 17 people. The vessel was sold to Germany, where it could be operated with a crew of $14 .{ }^{59}$

The third reason was that social costs were higher than in many of the competing countries. Gradually, Norwegian seafarers managed to win rights that made their working lives more agreeable, but at the same time they became less attractive from a competition point of view. In 1939 seafarers were given partial compensation for the cost of returning to Norway after three years at sea — a moot point, given that the war made such a return impossible or undesirable. A new Seaman's Act in 1953

\footnotetext{
${ }^{58}$ Calculated on the basis of gross tonnage data from Lloyd's Statistical Tables 1980, Table 17, based on all vessels larger than 100 gross tons. Given the properties of the Norwegian fleet, a comparison based on dead weight tonnage would give an even larger increase in the size difference.

${ }^{59}$ Thowsen and Tenold (2006, 256-265).
} 
granted a paid-for return to Norway after 24 months of service. ${ }^{60}$ This was reduced to 18 months five years later, to 12 months in the middle of the 1960s, nine months in 1971 and six months in $1973 .{ }^{61}$ Given that the Norwegian fleet still operated all over the world, the cost of sending home seafarers was substantial.

Norwegian shipping companies acted rationally and according to economic theory. The relative price of the factors of production in Norwaythe fact that capital was relatively cheap and accessible, and labour relatively expensive-should be reflected in investment behaviour. To remain competitive, shipping companies should invest in ships that used the relatively inexpensive factor (capital) intensively, and try to avoid using the expensive factor (labour). The solution—for most—was large and expensive ships.

\section{Survival of the Fittest}

Economies of scale at the ship level—large vessels with limited need for seafarers-enabled the Norwegian shipping industry to compete internationally. However, if we take a closer look at the fabric of the Norwegian shipping industry, we see that not all shipping companies had the same ability to compete. In particular, there was a tendency for the larger shipping companies to grow faster. The proportion of the fleet owned by the 30 largest shipping companies increased from slightly more than 50 per cent in 1950 , to almost 60 per cent by $1970 .{ }^{62}$ It is evident that many smaller shipping companies were unable to stay in business.

In 1960 a total of 174 Norwegian shipping companies owned vessels larger than 5000 grt, spread across 26 different home ports. During the

\footnotetext{
${ }^{60}$ The 1953 Act also stated that boys had to be at least 15 years old and girls at least 20 years old to be lawfully employed onboard.

${ }^{61}$ The 1939 arrangement was financed one-third each by the authorities, the shipping companies and the seafarers, and came into force after three years, or two years for ships trading in European waters. The service time could be extended by two to three months if the ship would be approaching ports that were closer to home and from which the cost of returning the seafarer would be significantly lower. The 1953 Act and subsequent improvements stipulated that the shipping company and the authorities would split the bill fifty-fifty. From 1975 the regulation also included Norwegians living abroad.

${ }^{62}$ Bakka (2017, 121).
} 
"good times" in the 1960s and early 1970s more than half of the companies that only owned one or two ships disappeared. However, they tended to be replaced by newly established enterprises_-by 1973 there had been a net reduction of only three companies. ${ }^{63}$

In comparison, only 11 per cent of the companies that owned from three to nine ships disappeared, and there were no exits at all among the companies that owned more than 10 ships. ${ }^{64}$ This suggests that the smaller shipping companies had a clear handicap during the boom period. One explanation for this handicap might be that in a period of rapid technological change, where it was necessary to invest in more expensive ships to remain competitive, smaller companies had insufficient funds to replace their ageing capital. Consequently, they became victims of the improved productivity of their competitors.

Some smaller shipping companies chose cooperation as a survival strategy. One possibility - for companies that could not buy a large and expensive vessel on their own-was to enter into partnerships with other owners, for instance by providing part of the equity for new bulk ship investments. Another possibility was to piggyback on the companies that chose a specialization strategy. Within these segments, the economies of scale were often related to the size of the fleet, rather than the size of the ship. ${ }^{65}$

The specialized segments were particularly well-suited for investments by shipping companies that were unable to keep up with the rapidly escalating newbuilding prices in the bulk market. Very often one of the "larger" shipping companies would be in the driving seat, with the knowledge and the strength needed to be competitive. However, there would sometimes be a symbiotic relationship with smaller shipping companies. An example from the chemical parcel tanker market illustrates this mechanism.

\footnotetext{
${ }^{63}$ The data set used for this calculation is presented in Tenold and Aarbu (2011), where the reinvestment problems that smaller shipping companies faced are analysed in detail.

${ }^{64}$ The rate of the decline for the smallest companies was relatively uniform throughout the period, with a small acceleration after 1970. The medium-sized companies all disappeared in the second half of the 1960s and the first part of the 1970s.

${ }^{65}$ In other words, within specialized segments, it was beneficial to have a fleet of many smaller ships in order to reap the benefits of economies of scale, as one large ship would be incompatible with the trade pattern and parcel sizes. In the bulk segments, the economies of scale were primarily at the ship level; a large ship was more beneficial than many small ships.
} 
The transport of chemicals was a Norwegian speciality, and in the early 1970s the three dominant groups in this market all had their roots in Norway; Stolt-Nielsen, Odfjell and Anco. By 1973 the three companies owned almost 80 per cent of the tonnage in the market for parcel tankers larger than 6000 dwt. $^{66}$ The substantial market share that the Bergen company Odfjell had acquired was partly based on its pool partnership with one of Bergen's largest companies, Westfal-Larsen \& Co. However, there was an element of segmentation within the chemical tanker market, and Odfjell also participated with a number of smaller shipping companies in the operation of smaller chemical tankers.

Such cooperation enabled Odfjell to expand — and reap the benefits of a diversified and larger fleet—without committing too much of its own resources. The company could offer an improved service to its customers, and there were also commissions involved from the chartering of the ships. In the period 1965-1973, Odfjell bought 10 vessels together with smaller shipping companies, and only one of these companies owned any tonnage when they entered the partnership. The others had all disposed of their last vessels shortly before. One reason for their cooperation with Odfjell might be nostalgia, a desire to maintain their link to shipping. Another reason could be the aforementioned beneficial tax advantages of investing in new tonnage. ${ }^{67}$

\section{The Heyday of Norwegian Shipping}

The TV series Hvor seiler vi?, with its unvarnished presentation of Norwegian sailors abroad, created a very heated debate in Norway. Many people were offended by the suggestion that sailors in foreign ports had an above-average interest in alcoholic drinks and the local nightlife. A future Prime Minister, Jan Peder Syse, asked questions about the programme in Parliament, urging the national broadcaster to correct the "fake picture" that had been presented ${ }^{68} \mathrm{~A}$ radio debate about Hvor seiler

\footnotetext{
${ }^{66}$ Thowsen and Tenold $(2006,301)$; see also Murphy and Tenold (2008) for a more concise introduction to the market.

${ }^{67}$ Thowsen and Tenold (2006, 335-350).

${ }^{68}$ Norway, Parliament, Forhandlinger i Stortinget nr. 207, 270170, 1649-1651. Syse, who had previously worked for the shipping company Wilh. Wilhelmsen, referred to the "dismay and sorrow" that the programme had brought to many homes.
} 
$v i$ ? and its portrayal of Norwegian seafarers pushed "a suite for cello and piano and a programme on archaeology and ghosts at Østre Toten" off the broadcasting schedule on the country's only radio channel. ${ }^{69}$

The TV series, and a subsequent book by a radical publisher, had a clear political agenda. The interviewer, Gunnar Bull-Gundersen, had five years earlier initiated a campaign that raised the minimum age for rookie sailors from 15 to 16 years. In Hvor seiler vi? he presented seafarers' lives in a manner that was meant to stir debate: "If you don't remember the programmes, the subsequent debate in the newspapers is not easy to forget."70

The widespread debate illustrates the central role that shipping played in the Norwegian economy and society. In 1960 sailors were based in all but two of the 734 municipalities in Norway-so BullGundersen managed to stir up practically the whole country. ${ }^{71}$ And shipping was extremely important. According to the most comprehensive report on the Norwegian economy, published by Statistics Norway in 1965, "shipping plays the same role [in Norway] as large-scale manufacturing does in other countries - it is export-oriented, demands very much capital and it attracts labour and initiatives that in other countries and in different circumstances perhaps would have gone towards manufacturing." 72

In 1965 this was a good description of the Norwegian economy. Ten years later, the picture was changing. Twenty years later, Norwegian shipping had been dethroned from its hegemonic position.

\section{Bibliography}

P.F. Alderton (1973) Sea Transport. Operation and Economics (London/ Sunderland: Thomas Reed Publications Ltd.)

L. Allen (1954) A meteorologic and oceanographic analysis of the passage of the SS Warrior (Washington, DC: National Academy of Sciences - National Research Council)

\footnotetext{
${ }^{69}$ Arbeiderbladet, 221269, 18.

${ }^{70}$ Bok og Bibliotek, 1970, Vol. 37, NO. 4/5, 294.

${ }^{71}$ Brun $(1960,10)$.

${ }^{72}$ Statistics Norway (1965, 47-48).
} 
D. Bakka (2008) Linjer rundt Jorden - Historien om norsk linjefart (Bergen: Seagull Publishing)

D. Bakka (2017) Nasjonens are - Norsk rederinaring mellom marked og politikk (Bergen: Bodoni Forlag)

M. Boldt-Christmas, S. Fagerland Jacobsen \& A.E. Tschoegl (2001) 'The International Expansion of the Norwegian Banks', Business History, 43:3, 79-104

E. Brofoss (1959) 'Pengepolitisk lovgivning og frivillig samarbeid med kredittinstitusjonene', Sosialøkonomen, 13:1-2: 1, 30-33

F. Brun (1960) 'Handelsflåten og beskjeftigelsen', Sosialøkonomen, 14:5, 9-10

C. Cooper (2016) 'The Ghost Ships of Hanjin and Why They're Spoiling Christmas', Bloomberg, 9 September 2016

P. Dahl (1970) Skipsfart og Skipsbygning. Perspektivanalyse utarbeidet på vegne av NTNF's Komite for Skipsteknisk Forskning (Oslo: Norges TekniskNaturvitenskaplige Forskningsråd)

A. Damman (1958) Investeringspolitikk $i$ Norge etter krigen (Oslo: Næringsøkonomisk Forskningsinstitutt)

J. Devanney (2006) The Tankship Tromedy. The Impending Disasters in Tankers, Second Edition (Tavernier: CTX Press)

A. Donovan (1999) 'Longshoremen and Mechanization', Journal for Maritime Research, 1:1, 66-75

L. Dunn (1956) The World's Tankers (London: Adlard Coles Limited)

W.P. Dunphy (1979) 'Whalebacks,' The Mariner's Mirror, 65:4, 351-355

J.O. Egeland (1971) Vi skal videre: Norsk skipsfart etter den annen verdenskrig, perioden 1945-1970 (Oslo: H. Aschehoug \& Co.)

A.M. Fon (1995a) 'En stormakt i tørrbulk. En økonomisk-historisk analyse av norsk tørrbulkfart 1950-1973', PhD-thesis (Bergen: Norges Handelshøyskole)

A.M. Fon (1995b) 'Two Markets or One? - An Historical Study of Price. Behaviour in the Tanker and Dry Bulk Shipping Markets, 1955-1973', International Journal of Maritime History, 7:2, 115-134

E. Gjermoe (1968) Norske skipsaksjeselskaper etter krigen (Bergen: Skipsfartsøkonomisk Institutt)

E. Gjermoe (1972) Inntekten m.v. i norske skipsaksjeselskaper (Bergen: Skipsfartsøkonomisk Institutt)

G.B. Gundersen (1970) Hvor seiler vi? (Oslo: Pax Forlag)

T. Halvorsen (2007) Vi seiler for velstand og lykke (Oslo: Pax)

T. Halvorsen (2010) 'Vi var "degos, svartinger eller skjevøyde". Utlendinger i den norske handelsflåten 1950-75’, Arbeiderhistorie, 24, 203-223 
L. Johnman \& H. Murphy (1998) 'The Norwegian Market for British Shipbuilding, 1945-1967', Scandinavian Economic History Review, XLVI, No. 2, 55-78

Y. Kaukiainen (2006) 'Journey Costs, Terminal Costs and Ocean Tramp Freights: How the Price of Distance Declined from the 1870s to the 2000s', International Journal of Maritime History, 18:2, 26-43

Y. Kaukiainen (2012) 'The Advantages of Water Carriage: Scale Economies and Shipping Technology, c. 1870-2000', in G. Harlaftis, S. Tenold \& J.M. Valdaliso (2012) The World's Key Industry; History and Economics of International Shipping (Basingstoke: Palgrave Macmillan)

R.D. Knowles (2006) 'Transport shaping space: differential collapse in timespace', Journal of Transport Geography, 14, 407-425

S. Knutsen (1997) 'Staten og norsk skipsfinansiering 1955-1975', in B.L. Basberg, H.W. Nordvik \& G. Stang (eds) det lange løp. Essays i økonomisk historie tilegnet Fritz Hodne (Bergen: Fagbokforlaget)

S. Knutsen, E. Lange \& H.W. Nordvik (1998) Mellom naringsliv og politikk. Kredittkassen i vekst og kriser, 1918-1998 (Oslo: Universitetsforlaget)

E. Koren (2017) 'Sjøfolk og velferdsstaten', Arbeiderhistorie, 31, 107-123

M. Levinson (2006a) 'Container Shipping and the Decline of New York, 1955-1975', Business History Review, 80, 49-80

M. Levinson (2006b) The Box: How the Shipping Container Made the World Smaller and the World Economy Bigger (Princeton: Princeton University Press)

H. Mayer (1973) 'Some Aspects of Technological Change in Maritime Transportation', Economic Geography, 49:2, 145-155

E. Merok (2011) 'After the Boom: The Political Economy of Shipping in Norway in the Interwar Period,' in L.R. Fischer \& E. Lange (eds) New directions in Norwegian maritime history (St. Johns: IMEHA) 125-150

H. Murphy (2013) “"No Longer Competitive with Continental Shipbuilders": British Shipbuilding and International Competition, 1930-1960', International Journal of Maritime History, 25:2, 35-60

H. Murphy \& S. Tenold (2008) 'Strategies, market concentration and hegemony in chemical parcel tanker shipping, 1960-1985', Business History, 51:3, 291-309

National Research Council (1956) Longshore Safety Survey - A Survey of Occupational Hazards In the Stevedore Industry (Washington, DC: National Academy of Sciences - National Research Council)

E. Nyquist \& W.E. Wiik (1972) Kapitalplassering (Oslo: Johan Grundt Tanum Forlag)

F. Olstad (2006) Var skjebne i vår hand (Oslo: Pax Forlag)

K. Petersen (1979) Skipsfinansiering $i$ medgang og motgang - Redernes Skibskreditforening, 1929-1979 (Kristiansand: Redernes Skibskreditforening) 
F. Platou \& B. Stokke (1980) Skip, Verksted og Finansiering - En studie av A/S Låneinstituttet for skipsbyggeriene (Oslo: Sjørettsfondet)

R.T. Poulsen (2007) 'Liner shipping and technological innovation: Ostasiat and the container revolution, 1963-75', Scandinavian Economic History Review, $55: 2,83-100$

R.T Poulsen (2010) 'The Emergence of New Organisational Forms in Liner Shipping: Swedish liner shipping and international consortia, 1960-75', Journal of Transport History, 31:1, 69-88

G. Sager \& E.W. Panting (1990) Maritime Capital. The Shipping Industry in Atlantic Canada, 1820-1914 (Montreal \& Kingston: McGill-Queens University Press)

F. Sejersted (ed) (1982) En storbank i blandingsøkonomien. Den norske Credibank 1957-1982 (Oslo: Gyldendal Norsk Forlag)

J. Seland (1959) 'Rundebords-konferanseinnlegg', Sosialøkonomen, 13:1-2, 43-48

J. Seland (1960) 'Enkelte finansierings- og skatteproblemer i skipsfartsnæringen', Sosialøkonomen, 14:5, 11-12

Statistics Norway (1965) Norges økonomi etter krigen (Oslo: Statistisk Sentralbyrå)

M. Stopford (2009) Maritime Economics, third edition (London: Routledge)

A.S. Svendsen (1957) Skipsfartspolitikken i Norge etter krigen (Bergen: Institute for Shipping Research)

A.S. Svendsen (1964) Skipsfartspolitikken i Norge etter krigen, Second updated edition (Bergen: Institute for Shipping Research)

E. Søilen (1998) 'Fra frischianisme til keneysianisme? En studie av norsk økonomisk politikk i lys av økonomisk teori', PhD-thesis (Bergen: Norges Handelshøyskole)

P. Temin (1997) 'The Golden Age of European Growth: a review essay', European Review of Economic History, Vol. 1, No. 1, 127-149

S. Tenold (2015a) Geared for Growth. Kristian Gerhard Jebsen and His Shipping Companies (Bergen: Bodoni Forlag)

S. Tenold (2015b) 'Globalisation and maritime labour in Norway after World War II', The International Journal of Maritime History, 27:4, 774-792

S. Tenold \& K.O. Aarbu (2011) 'Little Man, What Now? Company Deaths in Norwegian Shipping, 1960-1980', in L.R. Fischer \& E. Lange (eds) New directions in Norwegian maritime history (St. Johns: IMEHA) 233-252

A. Thowsen \& S. Tenold (2006) Odffell - The history of a shipping company (Bergen: Odfjell ASA) 
H. Van der Wee (1986) Prosperity and Upheaval: The World Economy, 1945-1980 (London: Viking)

S. Vanfraechem (2012) 'Why they are tall and we are small! Competition between Antwerp and Rotterdam in the twentieth century', in G. Harlaftis, S. Tenold \& J.M. Valdaliso (2012) The World's Key Industry; History and Economics of International Shipping (Basingstoke: Palgrave Macmillan)

E. Vea, J. Schreiner \& J. Seland (1960) Den Norske Amerikalinje 1910-1960 (Oslo: Grøndahl \& Søn)

A. Vigarié (1999) 'From Break-bulk to Containers: The Transformation of General Cargo Handling and Trade,' GeoJournal, 48:1, 3-7

D. Vikøren (1967) 'Merchant Marine Policy of Norway', manuscript (Oslo: Norwegian Shipowners' Association)

D.M. Williams (1968) 'Bulk carriers and timber imports: the British NorthAmerican trade and the shipping boom of 1824-25', Mariner's Mirror, 54:4, 373-382

R.T. Young (1971) 'New ships need new ports', Tidjschrift voor vervoerswetenschap, 7:1, 19-24

N. Aars-Nicolaysen (1959) 'Bedriftslivets finansieringsproblemer', Sosialøkonomen, No. 1-2, 1959, 24-29

Open Access This chapter is licensed under the terms of the Creative Commons Attribution-NonCommercial-NoDerivatives 4.0 International License (http:// creativecommons.org/licenses/by-nc-nd/4.0/), which permits any noncommercial use, sharing, distribution and reproduction in any medium or format, as long as you give appropriate credit to the original author(s) and the source, provide a link to the Creative Commons license and indicate if you modified the licensed material. You do not have permission under this license to share adapted material derived from this chapter or parts of it.

The images or other third party material in this chapter are included in the chapter's Creative Commons license, unless indicated otherwise in a credit line to the material. If material is not included in the chapter's Creative Commons license and your intended use is not permitted by statutory regulation or exceeds the permitted use, you will need to obtain permission directly from the copyright holder.

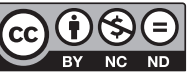

